\title{
Effect of Deficit Irrigation in Rabi Maize for Crop Growth, Yield, Biomass and Water Use Efficiency in North Bihar Condition
}

\author{
Vicky Kumar", Ravish Chandra and S. K. Jain \\ Department of Soil and Water Engineering, C.A.E., Dr. Rajendra Prasad Central Agricultural \\ University, Pusa, Bihar, India \\ *Corresponding author
}

\section{A B S T R A C T}

A field experiment was conducted in Rabi season of 2016-17 at experimental field of AICRP on Irrigation Water Management, Dr. Rajendra Prasad Central Agricultural University, Pusa (Bihar), India. This experiment was undertaken to study the response of different levels of irrigation on crop growth, yield, biomass and water use efficiency of Rabi maize under different levels of furrow irrigation under different treatments. The experiment was laid out in randomized block design with four treatment, five replication and five irrigations were applied in the main plot. The growing

\section{Keywords}

Zea mays L., Deficit irrigation, furrow irrigation, crop growth, biomass and water use efficiency

\section{Article Info}

Accepted: 20 May 2018 Available Online: 10 June 2018 season was divided into three phases: vegetative, flowering and grain filling. The irrigation treatments consisted of all possible combinations of full irrigation or limited irrigation in such that $\mathrm{T}_{1}$ (full/control irrigation), $\mathrm{T}_{2}$ ( $75 \%$ of $\left.\mathrm{CI}\right), \mathrm{T}_{3}\left(50 \%\right.$ of $\mathrm{CI}$ ) and $\mathrm{T}_{4}$ (Rainfed /No Irrigation). The biometric parameters like plant height, stem diameter, number of leaves and canopy spread were significantly superior in treatment $\mathrm{T}_{1}$ (control/full irrigation) compared to other deficit irrigation and rainfed treatments. The biometric parameters like plant height, stem diameter, number of leaves and canopy spread for treatment $T_{1}$ (control/full irrigation) was $179.80 \mathrm{~cm}, 29.90 \mathrm{~mm}, 12$ and $87.70 \mathrm{~cm}$ respectively. Rabi maize yield was highest for treatment $\mathrm{T}_{1}$ with a value of $11.12 \mathrm{t} / \mathrm{ha}$, followed by treatment $\mathrm{T}_{2}(75 \%$ of $\mathrm{CI})$ with a value of $10.98 \mathrm{t} / \mathrm{ha}$ and lowest for treatment $\mathrm{T}_{4}$ (Rainfed) with a value of $3.35 \mathrm{t} / \mathrm{ha}$. Biomass was highest for treatment $\mathrm{T}_{1}(\mathrm{CI})$ with a value of $24.92 \mathrm{t} / \mathrm{ha}$, followed by treatment $\mathrm{T}_{2}\left(75 \%\right.$ of $\mathrm{CI}$ ) with a value of $24.65 \mathrm{t} / \mathrm{ha}$ and lowest treatment $\mathrm{T}_{4}$ (Rainfed) with the value of $7.931 \mathrm{t} / \mathrm{ha}$. The crop yield and biomass were significantly higher for treatment $\mathrm{T}_{1}$ (control/full irrigation) compared to other treatments. The water use efficiency of Rabi maize yield decreased with increase in irrigation level for all treatments of furrow irrigation. Water use efficiency was highest for treatment $T_{3}$ with a value of $310 \mathrm{~kg} / \mathrm{ha}-\mathrm{cm}$ followed by treatment $\mathrm{T}_{2}$ with a value of 303 $\mathrm{kg} / \mathrm{ha}-\mathrm{cm}$. The water use efficiency was significantly higher treatment $\mathrm{T}_{3}(50 \%$ of $\mathrm{CI})$ compared to other treatments. The adapted values of canopy growth coefficient and canopy decline coefficient were $15.4 \%$ day $^{-1}$ and $9.5 \%$ day $^{-1}$ respectively for Rabi maize. The days of emergence, sowing to flowering, senescence and maturity were $6,60,142$ and 161 days respectively. The adopted values of water productivity (WP) were obtained as $30.7 \mathrm{~g} \mathrm{~m}^{-2}$. The harvest index was obtained as $48 \%$.

\section{Introduction}

Drought is one of the most common environmental stresses that may limit agricultural production worldwide. Many crops, including maize, have high water requirements and in most countries, supplemental irrigation is necessary for successful crop production. However, in many countries as a consequence of global climate changes and environmental pollution, water use for agriculture is reduced. Therefore, high 
emphasis is placed in the area of irrigation engineering, crop physiology and crop management for dry conditions with the aim to make plants more efficient in water use. Deficit irrigation is an optimization strategy in which irrigation is applied during droughtsensitive growth stages of a crop. Outside these periods, irrigation is limited or even unnecessary if rainfall provides a minimum supply of water. Water restriction is limited to drought-tolerant phenological stages, often in vegetative stages and the late ripening period. Total irrigation application is therefore not proportional to irrigation requirements throughout the crop cycle (Geerts and Raes, 2009). To cope with scarce supplies, deficit irrigation, defined as the application of water below full crop-water requirements (evapotranspiration), is an important tool to achieve the goal of reducing irrigation water use. While deficit irrigation is widely practiced over millions of hectares for a number of reason, from inadequate network design to excessive irrigation expansion relative to catchment supplies, it has not received sufficient attention in research. Its use in reducing water consumption for biomass production, and for irrigation of annual and perennial crops is reviewed here (Fereres and Soriano, 2006). While this inevitably results in plant drought stress and consequently in production loss, DI maximizes water productivity, which is the main limiting factor. In other words, DI aims at stabilizing yields and at obtaining maximum WP rather than maximum yields (Zhang et al., 2004). In the literature, the terms 'supplemental irrigation' and 'deficit irrigation' are both used. The first term generally refers to a rain-fed crop receiving additional irrigation during the whole season or during sensitive growth stages, whereas DI generally refers to fully irrigated crops from which water is withheld during certain tolerant growth stages. Knowing the response of crops to limited water supplies under specific environment is crucial to be able to implement deficient irrigation strategies for reducing agricultural water stress on Rabi maize yield in North Bihar condition.

Maize (Zea mays L.) is an important cereal crop in the world after wheat and rice, occupying an area of 146 million hectares with a production of 685 million tons and average productivity of $4.7 \mathrm{t} \mathrm{ha}^{-1}$ (FAOSTAT, 2015). Maize ranks third among cereal crops in India after rice and wheat, with an area of 9.3 million hectares, with a production of 23.67 million tons (Directorate of Economics Statistics, 2014-15). The current production of maize in India is $2.5 \mathrm{t} \mathrm{ha}^{-1}$ which are far below the global average of $5.0 \mathrm{tha}^{-1}$. In India, maize is cultivated throughout the year in most of the states of the country for various purposes including grain, fodder, green cobs, sweet corn, baby corn, popcorn and industrial products. There are three distinct seasons for the cultivation of maize in India: Kharif, Rabi in peninsular India and Bihar, and Spring in northern India. Bihar is one of the major maize growing states contributing nearly $8.9 \%$ of the total maize production of the country with nearly 0.28 million hectares being cultivated under maize per year. Maize is predominately a Kharif Season crop, but in past few years, Rabi maize has gained a significant place in total maize production in India. Rabi maize is grown on an area of 1.2 million ha with the grain production of 5.08 million tons, with an average productivity of 4.0 t/ha. The Rabi maize in Bihar state is occupying 0.412 million hectares area out of a total area of 0.645 million hectares during 2010-11. This indicates the acceptance of Rabi maize technology by farmers of this state by clear-cut comparative advantage over Kharif maize due to the low incidence of disease and insects-pests as well as the slow growth of weeds. These factors singly and in combination favored the adoption of Rabi maize cultivation in Bihar. The rainfall during 
$R a b i$ is rather inadequate for successful cultivation of high-yielding maize hybrids. In fact, timely availability of assured irrigation is one of the major factors determining the success of the crop. Where soil is light, it is desirable to schedule the irrigation $70 \%$ soil moisture availability through the period of crop growth and development. In heavy soils, a moisture level of $30 \%$ during the vegetative stage and $70 \%$ during thereby the reproductive and grain-filling period is desirable for obtainable optimum yield four to five irrigations are needed during the Rabi crop season. The rainfall during Rabi is rather inadequate for successful cultivation of highyielding maize hybrids. In fact, timely availability of assured irrigation is one of the major factors determining the success of the crop. Keeping the importance of deficit irrigation and water stress, the present study was undertaken to evaluate the effect of deficit irrigation on crop growth, yield and water use efficiency of Rabi Maize in eastern IGP.

\section{Materials and Methods}

The experimental site is located at the farm of Irrigation Water Management, Dr. Rajendra Prasad Central Agricultural University, Pusa, Samastipur, Bihar, India on the southern and western bank of the river Burhi Gandak at $25^{\circ} 59^{\prime} \mathrm{N}$ latitude and $85^{\circ} 48^{\prime} \mathrm{E}$ longitude. Altitude of the site is $52.92 \mathrm{~m}$ above mean sea level. The plot had a fairly uniform topography and the soil was deep and well drained. The soil was calcareous which was characterized by the presence of $26.6 \%$ calcium carbonate. It consists of sandy loam with sand (57\%), silt (31\%) and clay (12\%). The average bulk density, field capacity, and permanent wilting point were $1.63 \mathrm{~g} / \mathrm{cm}^{3}$, $19.62 \%$, and $7.2 \%$ respectively. The field was once plowed deep $(20-25 \mathrm{~cm})$ with soil turning plow. After that $4-5$ times plowing with cultivator was done. Two plantings were done to make the surface smooth. The layout of the experiment was prepared according to experiment plan. The seeds of Rabi maize (variety - DKC 9120) were sown with a spacing of $60 \mathrm{~cm} \times 100 \mathrm{~cm}$ on Nov. 4, 2016, on the raised beds of sterilized soil. The experiment was laid out in a randomized block design with four treatment, five replication, with a plot size of $7 \mathrm{~m} \times 6 \mathrm{~m}$ and five irrigations were applied in the main plot in Rabi season of 2016-17. The treatment details of experiments are presented below:

\section{Details of biometric observation}

Five plants were randomly selected from each replication, and selected plants were tagged for identification. For taking such as plant height, stem diameter, number of leaves per plant, canopy spread and crop yield were recorded. The observations were recorded at 30 days interval after 30 days of sowing.

\section{Plant height}

Three plants are randomly selected and tagged plants. The observation was recorded by measuring the vertical distance in centimeter from the upper surface of the soil touching the stem up to the maximum of the topmost fully opened leaf.

\section{Stem diameter}

Observation was recorded by measuring the stem circumference from the base of the tagged plant in centimeter, and again this circumference is divided by $\boldsymbol{\pi}$ then we get stem diameter of the plant.

\section{Number of leaves per plant}

The number of green leaves was counted from base leaf to the fully opened leaf. For convenience sake, tagging was done on the lower and older leaves to facilitate the counting of leaf number in the later stage. 


\section{Canopy spread}

Observation was recorded by measuring the length and breadth of leaves in $\mathrm{cm}$. Again adding to length and breadth, the sum is divided by two then we get canopy spread of the tagged plant.

\section{Statistics}

To determine the effects of the different irrigation treatments analysis of Coefficient of Variation, Means with Critical Difference and contrast analysis was performed using the Web-Based Agricultural Statistics Software Package (WASP-ICARGOA).

\section{Results and Discussion}

\section{Growth and Growth Attributes}

The data of biometric parameters like plant height, stem diameter, number of leaves per plant and canopy spread are presented in Table 2. The data on growth attributing characters revealed that plant height, stem diameter, number of leaves per plant and canopy spread are significantly superior in treatments $T_{1}$ and $T_{2}$. The plant height of tagged plants were measured at 30, 60, 90 and 120 days after sowing (DAS). The plant height of maize affected by the different level of irrigation is presented in Table 2. The plant height in control irrigation $\left(\mathrm{T}_{1)}\right.$ was higher by $72.78 \%$ compared to $\mathrm{T}_{4}$ (Rainfed) and $14.87 \%$ compared to $\mathrm{T}_{3}(50 \%$ of $\mathrm{CI})$ at $120 \mathrm{DAS}$. The plant height of maize under treatments $\mathrm{T}_{1}$ and $\mathrm{T}_{2}$ were at par. The highest and lowest plant height for Rabi maize were $179.80 \mathrm{~cm}$ and $104.06 \mathrm{~cm}$ respectively. The higher height of crop in treatments $T_{1}$ and $T_{2}$ might be due to better availability of soil moisture and temperature at an optimum level.

The data related to stem diameter of Rabi maize as affected by the different level of irrigation are presented in Table 2. The analysis revealed that control irrigation,i.e., treatment $\mathrm{T}_{1}$ was superior compared to treatment $\mathrm{T}_{2}(75 \%$ of $\mathrm{CI}), \mathrm{T}_{3}(50 \%$ of $\mathrm{CI})$ and $\mathrm{T}_{4}$ (Rainfed). The stem diameter under control irrigation $\left(\mathrm{T}_{1}\right)$ was higher by $43.75 \%$ compared to $\mathrm{T}_{4}$ (Rainfed), $17.25 \%$ compared to $\mathrm{T}_{3}(50 \%$ of $\mathrm{CI})$ and $5.28 \%$ compared to $\mathrm{T}_{2}$ (75\% of CI) at 120 DAS. The highest and lowest stem diameter for Rabi maize were $29.90 \mathrm{~mm}$ and $20.80 \mathrm{~mm}$ respectively. The better performance in treatments $T_{1}$ and $T_{2}$ may be due to the uniform application of water at the right time and in right amount during the crop period.

The nature of increment in number of leaves with respect to time after sowing is shown in Table 2. The average number of leaves per plant of Rabi maize after 120 days of sowing were $12,12,11$ and 10 for treatment $\mathrm{T}_{1}(\mathrm{CI})$, $\mathrm{T}_{2}(75 \%$ of $\mathrm{CI}), \mathrm{T}_{3}(50 \%$ of $\mathrm{CI})$ and $\mathrm{T}_{4}$ (Rainfed) respectively. The treatment of variation is almost similar to that of other growth parameters such as plant height. The analysis suggested that control irrigation, i.e., treatment $\mathrm{T}_{1}(\mathrm{CI})$ and treatment $\mathrm{T}_{2}(75 \%$ of $\mathrm{CI})$ is superior compared to $\mathrm{T}_{3}(50 \%$ of $\mathrm{CI})$ and $\mathrm{T}_{4}$ (Rainfed). Treatments $\mathrm{T}_{1}$ and $\mathrm{T}_{2}$ are statistically at par. The number of leaves per plant under control irrigation $\left(\mathrm{T}_{1}\right)$ was higher by $20 \%$ compared to $\mathrm{T}_{4}$ (Rainfed) and $9.1 \%$ compared to $\mathrm{T}_{3}(50 \%$ of $\mathrm{CI})$. The more number of leaves in care of treatment $\mathrm{T}_{1}(\mathrm{CI})$ and $\mathrm{T}_{2}(75 \%$ of $\mathrm{CI})$ were mainly due to better vegetative growth compared to $\mathrm{T}_{4}$ (Rainfed).

Canopy spread is one of the important biometric parameters of crop growth. The recorded data on canopy spread of Rabi maize under a different level of irrigation. Treatment and their analysis of variance are shown in Table 2. The maximum plant canopy spread was recorded for treatment $\mathrm{T}_{2}(75 \%$ of $\mathrm{CI})$ followed by $\mathrm{T}_{1}(\mathrm{CI})$ and lowest for treatment $\mathrm{T}_{4}$ (Rainfed). 
Table.2 Different crop growth, grain yield, biomass of Rabi maize and water use efficiency as influenced by different treatments

\begin{tabular}{|c|c|c|c|c|c|c|c|}
\hline \multirow[t]{2}{*}{$\mathbf{S . N}$} & \multirow[t]{2}{*}{ Parameters } & \multirow[t]{2}{*}{ DAS } & & \multicolumn{3}{|l|}{ Treatments } & \multirow[t]{2}{*}{ CD $(P<0.05)$} \\
\hline & & & $\mathrm{T}_{1}(\mathrm{CI})$ & $\mathrm{T}_{2}(75 \%$ of $\mathrm{CI})$ & $\mathrm{T}_{3}(50 \%$ of $\mathrm{CI})$ & $\mathrm{T}_{4}($ Rainfed $)$ & \\
\hline \multirow[t]{4}{*}{1.} & \multirow[t]{4}{*}{ Plant height (cm) } & 30 & $38.76^{\mathrm{a}}$ & $37.98^{\mathrm{a}}$ & $29.54^{\mathrm{b}}$ & $22.54^{\mathrm{c}}$ & 1.89 \\
\hline & & 60 & $78.56^{\mathrm{a}}$ & $78.52^{\mathrm{a}}$ & $63.26^{b}$ & $46.80^{c}$ & 2.60 \\
\hline & & 90 & $165.54^{\mathrm{a}}$ & $163.74^{\mathrm{a}}$ & $132.86^{b}$ & $76.26^{\mathrm{c}}$ & 4.05 \\
\hline & & 120 & $179.80^{\mathrm{a}}$ & $177.14^{\mathrm{a}}$ & $156.52^{b}$ & $104.06^{c}$ & 4.53 \\
\hline \multirow[t]{4}{*}{2.} & \multirow[t]{4}{*}{ Stem diameter, mm } & 30 & $11.70^{\mathrm{a}}$ & $11.50^{\mathrm{a}}$ & $9.60^{b}$ & $7.70^{c}$ & 0.90 \\
\hline & & 60 & $21.70^{\mathrm{a}}$ & $21.80^{\mathrm{a}}$ & $19.20^{b}$ & $13.80^{c}$ & 1.05 \\
\hline & & 90 & $29.10^{\mathrm{a}}$ & $28.00^{\mathrm{b}}$ & $25.10^{c}$ & $20.50^{d}$ & 0.88 \\
\hline & & 120 & $29.90^{\mathrm{a}}$ & $28.40^{b}$ & $25.50^{c}$ & $20.80^{d}$ & 0.53 \\
\hline \multirow[t]{4}{*}{3.} & \multirow[t]{4}{*}{ Number of leaves per plant } & 30 & $7^{\mathrm{a}}$ & $7^{\mathrm{a}}$ & $6^{b}$ & $6^{b}$ & 0.59 \\
\hline & & 60 & $9^{a}$ & $9^{a}$ & $8^{b}$ & $8^{b}$ & 0.63 \\
\hline & & 90 & $11^{\mathrm{a}}$ & $11^{\mathrm{a}}$ & $10^{\mathrm{b}}$ & $9^{c}$ & 0.79 \\
\hline & & 120 & $12^{\mathrm{a}}$ & $12^{\mathrm{a}}$ & $11^{\mathrm{b}}$ & $10^{c}$ & 0.98 \\
\hline \multirow[t]{4}{*}{4.} & \multirow[t]{4}{*}{ Canopy spread, cm } & 30 & $35.98^{\mathrm{a}}$ & $35.04^{\mathrm{a}}$ & $26.94^{b}$ & $22.60^{c}$ & 1.18 \\
\hline & & 60 & $77.76^{\mathrm{a}}$ & $75.80^{\mathrm{a}}$ & $61.62^{b}$ & $47.64^{c}$ & 3.36 \\
\hline & & 90 & $81.84^{\mathrm{a}}$ & $82.16^{a}$ & $75.84^{\mathrm{a}}$ & $59.30^{\mathrm{b}}$ & 7.73 \\
\hline & & 120 & $87.70^{a}$ & $89.06^{\mathrm{a}}$ & $81.22^{a}$ & $57.32^{\mathrm{b}}$ & 8.22 \\
\hline 5. & Grain yield (t/ha) & & $11.12^{\mathrm{a}}$ & $10.98^{\mathrm{a}}$ & $7.61^{\mathrm{b}}$ & $3.35^{\mathrm{c}}$ & 1.48 \\
\hline 6. & Biomass (t/ha) & & $24.92^{\mathrm{a}}$ & $24.65^{\mathrm{a}}$ & $16.49^{b}$ & $7.93^{\mathrm{c}}$ & 1.87 \\
\hline
\end{tabular}

Table.3 Water use efficiency of Rabi maize under different levels of irrigation

\begin{tabular}{|c|c|c|c|c|c|c|}
\hline Treatments & $\begin{array}{c}\text { Grain yield } \\
\text { (t/ha) }\end{array}$ & $\begin{array}{c}\text { Depth of } \\
\text { irrigation }(\mathrm{cm})\end{array}$ & Rainfall (cm) & Total water applied (cm) & $\begin{array}{l}\text { Water Use } \\
\text { Efficiency } \\
\text { (kg/ha-cm) }\end{array}$ & $\begin{array}{c}\text { Water } \\
\text { Productivity } \\
\left(\mathrm{kg} / \mathrm{m}^{3}\right)\end{array}$ \\
\hline T1(CI) & 11.12 & 46.90 & 1.06 & 47.96 & $232^{\mathrm{b}}$ & 2.32 \\
\hline $\mathrm{T} 2(75 \%$ of $\mathrm{CI})$ & 10.98 & 35.20 & & 36.26 & $303^{a}$ & 3.03 \\
\hline $\mathrm{T} 3(50 \%$ of $\mathrm{CI})$ & 7.61 & 23.50 & & 24.56 & $310^{\mathrm{a}}$ & 3.10 \\
\hline T4 (Rainfed) & 3.35 & - & - & - & - & - \\
\hline $\mathrm{CD}(\mathrm{P}<0.05)$ & & & & & 39.58 & \\
\hline
\end{tabular}


Table.1 Irrigations treatments details of experiments

Treatments

$\mathbf{T}_{1}$

$\mathbf{T}_{2}$

$\mathrm{T}_{3}$

$\mathrm{T}_{4}$

\section{Details of irrigation treatments}

$100 \%$ level of estimated crop water requirement based on cumulative pan evaporation (Control/Full irrigation)

$75 \%$ of CI (Treatment $\mathrm{T}_{1}$ )

$50 \%$ of $\mathrm{CI}$

Rainfed /No Irrigation

Table.4 The Empirical equation relating to an average plant height of maize with time for 30 days to 120 days

\begin{tabular}{|l|c|c|}
\hline \multicolumn{1}{|c|}{ Treatments } & Empirical equation & Coefficient of correlation \\
\hline $\mathrm{T}_{1}(\mathrm{CI})$ & $\mathrm{Y}=38.24 \mathrm{X}^{1.178}$ & $\mathrm{R}^{2}=0.970$ \\
\hline $\mathrm{T}_{2}(\mathbf{7 5} \%$ of $\mathrm{CI})$ & $\mathrm{Y}=37.69 \mathrm{X}^{1.182}$ & $\mathrm{R}^{2}=0.971$ \\
\hline $\mathrm{T}_{3}(\mathbf{5 0} \%$ of $\mathrm{CI})$ & $\mathrm{Y}=28.99 \mathrm{X}^{1.260}$ & $\mathrm{R}^{2}=0.981$ \\
\hline $\mathrm{T}_{4}(\mathrm{Rainfed})$ & $\mathrm{Y}=0.885 \mathrm{X}^{2}+22.97 \mathrm{X}-1.665$ & $\mathrm{R}^{2}=0.999$ \\
\hline
\end{tabular}

Table.5 The empirical equation relating to average stem diameter of maize with time for 30 days to 120 days

\begin{tabular}{|l|c|c|}
\hline \multicolumn{1}{|c|}{ Treatments } & Empirical equation & Coefficient of correlation \\
\hline $\mathrm{T}_{1}(\mathrm{CI})$ & $\mathrm{Y}=-2.295 \mathrm{X}^{2}+17.69 \mathrm{X}-3.935$ & $\mathrm{R}^{2}=0.996$ \\
\hline $\mathrm{T}_{2}(\mathbf{7 5} \%$ of $\mathrm{CI})$ & $\mathrm{Y}=-2.46 \mathrm{X}^{2}+17.99 \mathrm{X}-4.12$ & $\mathrm{R}^{2}=0.999$ \\
\hline $\mathrm{T}_{3}(50 \%$ of $\mathrm{CI})$ & $\mathrm{Y}=-2.3 \mathrm{X}^{2}+16.80 \mathrm{X}-5$ & $\mathrm{R}^{2}=0.999$ \\
\hline $\mathrm{T}_{4}$ (Rainfed) & $\mathrm{Y}=-0.144 \mathrm{X}^{2}+11.77 \mathrm{X}-2.94$ & $\mathrm{R}^{2}=0.979$ \\
\hline
\end{tabular}

Table.6 The empirical equation relating to average canopy length of maize with time for 30 days to 120 days

\begin{tabular}{|l|c|c|}
\hline \multicolumn{1}{|c|}{ Treatments } & Empirical equation & Coefficient of correlation \\
\hline $\mathrm{T}_{1}(\mathrm{CI})$ & $\mathrm{Y}=-8.98 \mathrm{X}^{2}+60.82 \mathrm{X}-13.89$ & $\mathrm{R}^{2}=0.953$ \\
\hline $\mathrm{T}_{2}(\mathbf{7 5} \%$ of $\mathrm{CI})$ & $\mathrm{Y}=-8.465 \mathrm{X}^{2}+59.16 \mathrm{X}-13.91$ & $\mathrm{R}^{2}=0.965$ \\
\hline $\mathrm{T}_{3}(\mathbf{5 0} \%$ of $\mathrm{CI})$ & $\mathrm{Y}=-7.325 \mathrm{X}^{2}+54.33 \mathrm{X}-19.48$ & $\mathrm{R}^{2}=0.996$ \\
\hline $\mathrm{T}_{4}($ Rainfed $)$ & $\mathrm{Y}=-6.755 \mathrm{X}^{2}+45.35 \mathrm{X}-16.01$ & $\mathrm{R}^{2}=0.999$ \\
\hline
\end{tabular}

The canopy spread under control irrigation $\left(\mathrm{T}_{1}\right)$ was higher by $53 \%$ compared to $\mathrm{T}_{4}$ (Rainfed) and $7.98 \%$ compared to $\mathrm{T}_{3}(50 \%$ of CI). The highest and lowest canopy spread for Rabi maize were 87.70 and $57.32 \mathrm{~cm}$ respectively. The analysis of the data revealed that control irrigation, i.e., treatment $\mathrm{T}_{1}$ and treatment $\mathrm{T}_{2}(75 \%$ of $\mathrm{CI})$ is superior compared to $\mathrm{T}_{3}(50 \%$ of $\mathrm{CI})$ and $\mathrm{T}_{4}$ (Rainfed). Treatments $\mathrm{T}_{1}$ and $\mathrm{T}_{2}$ are statistically at par. The better performance in treatments $\mathrm{T}_{1}$ and $\mathrm{T}_{2}$ may be due to the uniform application of water at the right time and in right amount during the crop period. The higher canopy spread was achieved in case of treatment $\mathrm{T}_{2}$ ( $75 \%$ of $\mathrm{CI}$ ) and $\mathrm{T}_{1}(\mathrm{CI})$ was done to good 
vegetative growth in terms of higher plant height, stem diameter and higher number of leaves per plant. Similar results were reported by other researcher (Manjunath. 1998, Madile et al., 2012).

The average grain yield and biomass recorded for Rabi maize is presented in Table 2 . Irrigation significantly $(\mathrm{P}<0.05)$ influenced the Rabi maize yield. The grain yield increases with the increase in levels of irrigation. The analysis of the data revealed that the Rabi maize yield was highest for treatment $\mathrm{T}_{1}(\mathrm{CI})$ with a value of $11.12 \mathrm{t} / \mathrm{ha}$, followed by treatment $\mathrm{T}_{2}(75 \%$ of $\mathrm{CI})$ with a value of $10.98 \mathrm{t} / \mathrm{ha}$ and lowest for treatment $\mathrm{T}_{3}(50 \%$ of $\mathrm{CI})$ with a value of $7.61 \mathrm{t} / \mathrm{ha}$. The grain yield in control $\mathrm{T}_{1}$ was higher by 232.40 $\%$ compared to $\mathrm{T}_{4}$ (Rainfed) and $46.21 \%$ compared to treatment $\mathrm{T}_{3}(50 \%$ of $\mathrm{CI})$. The grain yield of maize under treatments $T_{1}$ and $\mathrm{T}_{2}$ were at par. The higher grain yield of maize in treatments $T_{1}$ and $T_{2}$ might be due to better availability of soil moisture and temperature at an optimum level (Table 2). The highest biomass was recorded for treatment $\mathrm{T}_{1}(\mathrm{CI})$ with a value of $24.92 \mathrm{t} / \mathrm{ha}$, followed by treatment $\mathrm{T}_{2}(75 \%$ of $\mathrm{CI})$ with a value of $24.65 \mathrm{t} / \mathrm{ha}$. The lowest biomass was recommended for treatment $\mathrm{T}_{4}$ (Rainfed) with the value of $7.931 \mathrm{t} / \mathrm{ha}$. The biomass in treatment $\mathrm{T}_{1} \quad(\mathrm{CI})$ was $214.21 \%$ higher Compared to treatment $\mathrm{T}_{4}$ (Rainfed) and $51.13 \%$ higher compared to treatment $\mathrm{T}_{3}$ (50\% of CI). Similar results were reported by another researcher (Kang et al., 2000, Farre et al., 2009, Seid and Narayanan 2015). Better utilization of soil nutrients, higher photosynthesis under non-water stressed environment were responsible for achieving higher yield in treatment $T_{1}$ and $T_{2}$. The higher yield in control could be ascribed to different factors. It might be due to higher vegetative growth and LAI that is essential for intercepting. The radiation, which means more photosynthates are produced and allocated to cobs. The other factor could be optimum soil moisture condition during the crop growth period.

Water use efficiency (WUE) expressed as the ratio of grain yield to the total water applied. Table 3 shows the water use efficiency of Rabi maize under a different level of irrigation. Water use efficiency was highest for treatment $\mathrm{T}_{3}$ with a value of $310 \mathrm{~kg} / \mathrm{ha}-\mathrm{cm}$ followed by treatment $T_{2}$ with a value of 303 $\mathrm{kg} / \mathrm{ha}-\mathrm{cm}$ (Table 3.). The statistical analysis revealed that the water use efficiency was significantly higher in treatment $T_{3}$ compared to rest of the treatments. The depth of water applied in treatment $\mathrm{T}_{1}(\mathrm{CI})$ was $47.96 \mathrm{~cm}$. The water use efficiency of maize decreased with increase in irrigation levels for all treatments of furrow irrigation (Table 3.). Although the treatment $\mathrm{T}_{3}(50 \%$ of CI) received approximate $50 \%$ of water applied to control, the drought level may not be severe enough to decrease plant growth to the same degree. The data revealed that yield loss in deficit irrigation treatment $\mathrm{T}_{4}$ was only $31.60 \%$ compared to control whereas the amount of water applied was $50 \%$ of control. There is need of 322.6, 330 and 431 liters of water to produce $1 \mathrm{~kg}$ of maize for treatment $\mathrm{T}_{3}(50 \%$ of $\mathrm{CI}), \mathrm{T}_{2}(75 \%$ of $\mathrm{CI})$ and $\mathrm{T}_{1}(\mathrm{CI})$ respectively.

The empirical relations were also developed relating to an average plant height, average stem diameter and average canopy spread of Rabi maize with time under a different level of irrigation from Table 4 to 6.

Irrigation significantly influenced the biometric parameter of growth, yield, and biomass of Rabi maize. The crop yield and biomass were highest for treatment $\mathrm{T}_{1}$ (CI) having full irrigation and lowest for treatment $\mathrm{T}_{4}$ (Rainfed) having no irrigation. The water use efficiency was highest for treatment for treatment $\mathrm{T}_{3}(50 \%$ of $\mathrm{CI})$, followed by 
treatment $\mathrm{T}_{2}(75 \%$ of $\mathrm{CI})$ and lowest for treatment $\mathrm{T}_{1}(\mathrm{CI})$. Among different irrigation treatments, treatment $\mathrm{T}_{2}(75 \%$ of $\mathrm{CI})$ was found best and is recommended for Rabi maize in North Bihar condition.

\section{Acknowledgement}

I, hereby acknowledge the technical and financial help provided by AICRP on IWM, Dr. RPCAU, Pusa.

\section{References}

Directorate of Economics and Statistics, Ministry of Agriculture and Farmers Welfare. 2014-15. (online) http://eands.dacnet.nic.in/

FAOSTAT 2015. (online) http://faostat.fao.org.

Fereres, E., Soriano, M.A., 2006. Deficit irrigation for reducing agricultural water use. J. Exp. Bot. 58: 147-159.

Geerts, S. and Raes, D. 2009. Deficit irrigation as an on-farm strategy to maximize crop water productivity in dry areas. Agricultural Water Management, 96: 1275-1284.

Kang, S., Shi, W. and Zhang, J. 2000. An improved water use efficiency for maize grown under regulated deficit irrigation. Field Crops Research, 67 (3): 207-214.

Madile, A. K.; Singh, P. K.; Sharma, H.C.; Singh, R.D. and Joshi Ganga. 2012. Tensiometer based drip irrigation scheduling for enhancing water productivity of capsicum (Capsicum annum L.) under polyhouse. Indian Journal of Soil Conservation, 40 (1): 41-45.

Manjunath, M.V. 1998. Studies on testing and applicability of micro-irrigation and other irrigation systems in sweet lime intercropping. Ph. D. Thesis, GBPUA \&T, Pantnagar, pp: 273.

Seid, M.M. and Narayana, K. 2015. Effect of deficit irrigation on maize under conventional, fixed and alternate furrow irrigation system at melkassa, Ethiupia. International Journal of Engineering Research \& Technology (IJERT), 4: 119-126.

Zhang, Y.; Kendy, E.; Qiang, Y.; Changminga, L.; Yanjun, S. and Hongyong. S. 2004. Effect of soil water deficit on evapotranspiration, crop yield, and water use efficiency in the North China Plain. Agricultural Water Management, 64: 107-122.

\section{How to cite this article:}

Vicky Kumar, Ravish Chandra and Jain S. K. 2018. Effect of Deficit Irrigation in Rabi Maize for Crop Growth, Yield, Biomass and Water Use Efficiency in North Bihar Condition. Int.J.Curr.Microbiol.App.Sci. 7(06): 2694-2701. doi: https://doi.org/10.20546/ijcmas.2018.706.318 